\title{
Histoplasmosis in the nasal septum without pulmonary involvement in a patient with acquired immunodeficiency syndrome: case report and literature review
}

\author{
Histoplasmose no septo nasal sem envolvimento pulmonar em um paciente com sindrome da \\ imunodeficiência adquirida: relato de caso clínico e revisão de literatura
}

Fernando Oikawa', Daniela Carvalho', Nilce Mitiko Matsuda", Alice Tatsuko Yamada"I"

Hospital Municipal de Campo Limpo “Dr. Fernando Mauro Pires da Rocha”, São Paulo, Brazil

KEY WORDS:

Histoplasmosis.

Acquired immunodeficiency syndrome.

Nasal septum.

Histoplasma.

Human immunodeficiency virus (HIV).

PALAVRAS-CHAVE:

Histoplasmose.

Síndrome da imunodeficiência adquirida.

Septo nasal.

Histoplasma.

Vírus da imunodeficiência humana (HIV).

\begin{abstract}
CONTEXT: Histoplasmosis is a fungal disease caused by inhaling spores of the fungus Histoplasma capsulatum. The spores can be found in soil contaminated with bird, bat or chicken feces. Histoplasmosis occurs worldwide and is one of the most common pulmonary and systemic mycoses. CASE REPORT: We report here the case of a 37-year-old man with acquired immune deficiency syndrome and histoplasmosis in the nasal septum, without pulmonary involvement, that evolved rapidly to disseminated infection, multiple organ failure and death.
\end{abstract}

\section{RESUMO}

CONTEXTO: Histoplasmose é uma doença fúngica causada pela inalação de esporos do fungo Histoplasma capsulatum. Os esporos podem ser encontrados no solo contaminado com fezes de aves, morcegos ou galinhas. Histoplasmose ocorre em todo o mundo e é uma das mais comuns micoses pulmonares e sistêmicas.

RELATO DE CASO: Relatamos aqui o caso de um homem de 37 anos com síndrome da imunodeficiência adquirida e histoplasmose no septo nasal sem envolvimento pulmonar que evoluiu rapidamente para infecção disseminada, falência de múltiplos órgãos e morte.

\section{INTRODUCTION}

Histoplasmosis is caused by a dimorphic fungus, Histoplasma capsulatum, that grows in the form of mycelia in soil (its natural habitat), in the presence of bird, bat and chicken feces. ${ }^{1}$ The infection starts after inhalation of microspores and it is generally asymptomatic or selflimited. Histoplasmosis may also result in variety of clinical manifestations. The most frequent is an asymptomatic or self-limited influenza-like respiratory infection. ${ }^{1}$ However, it also can be manifested as acute pulmonary histoplasmosis, chronic pulmonary histoplasmosis and disseminated histoplasmosis. ${ }^{1}$

We report here the case of a 37-year-old man with histoplasmosis in the nasal septum, without pulmonary involvement, that evolved very rapidly to disseminated infection, multiple organ failure and death.

\section{CASE REPORT}

A 37-year-old man began to lose weight gradually after decreasing his food intake due to dysphagia in relation to both solid and liquid foods that began one month before admission. The decrease in food intake intensified over the last three days before his hospitalization because of an inflammatory and hemorrhagic process in his nose and fever. He did not have a cough, and had not had any previous similar episodes. Before hospitalization, the patient took several drugs without response. The patient's medical history included moderate-risk sexual behavior (no condom) during the preceding four years and pulmonary tuberculosis five years earlier.

He presented difficulty in his vocal pronunciation associated with the growth of the hemorrhagic and inflammatory process in his nose. He was extremely thin $(48 \mathrm{~kg})$ and presented significant edema in the

'MD. Resident physician, Hospital Municipal de Campo Limpo “Dr. Fernando Mauro Pires da Rocha”, São Paulo, SP, Brazil.

"MD, PhD. Research associate, Department of Surgery and Anatomy, Faculdade de Medicina de Ribeirão Preto, Universidade de São Paulo (FMRP-USP), Ribeirão Preto, SP, Brazil.

"'MD, PhD. Cardiologist, Instituto do Coração (InCor), Hospital das Clínicas (HC), School of Medicine, Universidade de São Paulo (USP), São Paulo, and Hospital Municipal de Campo Limpo “Dr. Fernando Mauro Pires da Rocha”, São Paulo, SP, Brazil. 
nasal area. He had an intermittent high temperature, which reached 40 ${ }^{\circ} \mathrm{C}$, accompanied by chills. His pulse and blood pressure were normal, and heart and lung examinations showed normal results.

There were multiple non-painful lymph nodes of hard consistency in his neck. His nasal region showed phlogistic signs and skin fistulae, with bloody and purulent active secretion into the right ala, and other oronasal fistulae. The right nasal septum was very friable with tissue destruction.

The laboratory values were as follows: hemoglobin, $10.9 \mathrm{~g} / \mathrm{dl}$; hematocrit, 33.7\%; platelets, 106 ; and white cell count, $3800 / \mathrm{mm}^{3}$, with $1 \%$ metamyelocytes, $2 \%$ less mature neutrophils (bands), $90 \%$ segmented neutrophils, $1 \%$ eosinophils, $5 \%$ lymphocytes and $1 \%$ monocytes. The aminotransferase levels were abnormal (aspartate, 774; and alanine, 136) and the albumin level was 2.1. The serological tests confirmed that the patient presented acquired immunodeficiency syndrome (AIDS). Chest radiographs were normal.

After the patient had been admitted to hospital, he was prescribed oxacillin, but this did not produce any response. This was then replaced by ceftriaxone, again without success. During hospitalization, computed tomography was performed, showing significant destruction of the nasal septum, with an image suggestive of severe nasal infection. Biopsies of the nasal septum lesion and lymph nodes were performed. At this point, metronidazole ( $400 \mathrm{mg}$, three times a day) was prescribed.

The following week, the patient presented intense vomiting, diarrhea, daily fever, nasal and oral hemorrhagic processes, anorexia and more weight loss. The patient began to show significant pancytopenia and two red blood cell packs were prescribed. The patient progressed badly and died a few days later.

The cervical lymph node that was biopsied did not reveal any histopathological alterations. From the biopsy material taken from the lesion in his nose and nasal septum, the fungus Histoplasma capsulatum was isolated.

\section{DISCUSSION}

Both pulmonary involvement and disseminated disease are very common manifestations of histoplasmosis in immunocompromised patients presenting AIDS or chronic illness. ${ }^{2-4}$

Due to the small size of the fungal tissue (2-4 $\mu \mathrm{m}$ in diameter), and its similarity with other elements of yeast and other fungal struc- tures, the definitive diagnosis of histoplasmosis is achieved by isolating the fungus in cultures. ${ }^{1}$ Thus, the diagnosis may take a long time to be established, and sometimes the treatment cannot be implemented in time. ${ }^{1-4}$ This was the case with our patient: only after his death was the definitive diagnosis of histoplasmosis made from the biopsy material that had been taken from his nasal septum during his hospitalization.

Because most of the clinical manifestations of histoplasmosis simulate tuberculosis, and the rapid clinical deterioration leads to multiple organ failure and death, histoplasmosis in our patient without pulmonary involvement was not diagnosed. Cases of histoplasmosis with skin lesions have been described among immunocompromised patients with AIDS. ${ }^{5-22}$ Although rare, patients with AIDS and skin lesions but without lung involvement have also been reported recently. ${ }^{5-8}$ Furthermore, an unusual orofacial case of manifestations of histoplasmosis in immunocompromised renal transplanted patient has also been described. ${ }^{10}$ Therefore, our objective in presenting this case was to draw attention to the diagnosis of histoplasmosis among patients with skin lesions alone, in the absence of pulmonary involvement, because such cases can also evolve very rapidly to systemic infection, multiple organ failure and death, especially among patients with AIDS. ${ }^{2-7}$ We performed a search in the relevant databases (Cochrane Database of Systematic Reviews; Embase Biomedical Answers; Literatura Latino-Americana e do Caribe em Ciências da Saúde; and United States National Library of Medicine and National Institutes of Health) for nasal septum and histoplasmosis, and the results are presented in Table $1 .^{9,10,23}$

\section{CONCLUSIONS}

The special feature of this case report is that it presents the history of a 37-year-old man with AIDS and histoplasmosis in the nasal septum without pulmonary involvement who progressed very rapidly to disseminated infection, multiple organ failure and death. When there is no pulmonary involvement, the definitive diagnosis depends on isolation of the fungus in culture, which takes a long time. In these cases, in which the rapid progression of the disease prevents proper treatment, the diagnosis of histoplasmosis depends on a high degree of suspicion.

Table 1. Search in relevant databases for nasal septum and histoplasmosis

\begin{tabular}{|c|c|c|c|c|}
\hline Databases & Search strategy & & Results & \\
\hline Cochrane & Nasal septum AND Histoplasmosis & 0 article found & 0 related article & - \\
\hline Embase & Nasal septum AND Histoplasmosis & 2 articles found $d^{9,10}$ & 2 related articles & 2 case reports \\
\hline Lilacs & Nasal septum AND Histoplasmosis & 1 article found $^{23}$ & 0 related article & 1 case report \\
\hline PubMed & Nasal septum AND Histoplasmosis & 2 articles found $d^{10,23}$ & 1 related article & 2 case reports \\
\hline
\end{tabular}

Cochrane = Cochrane Database of Systematic Reviews; Embase = Embase Biomedical Answers; Lilacs = Literatura Latino-Americana e do Caribe em Ciências da Saúde; PubMed = United States National Library of Medicine and National Institutes of Health. 


\section{REFERENCES}

1. Kauffman CA. Histoplasmosis. Clin Chest Med. 2009;30(2):217-25.

2. Solari R, Corti M, Cangelosi D, et al. Disseminated histoplasmosis with lesions restricted to the larynx in a patient with AIDS. Report of a case and review of the literature. Rev Iberoam Micol. 2007;24(2):164-6.

3. Bhagwat PV, Hanumanthayya K, Tophakhane RS, Rathod RM. Two unusual cases of histoplasmosis in human immunodeficiency virus-infected individuals. Indian J Dermatol Venereol Leprol. 2009;75(2):173-6.

4. K Ramdial P, Mosam A, Dlova NC, et al. Disseminated cutaneous histoplasmosis in patients infected with human immunodeficiency virus. J Cutan Pathol. 2002;29(4):215-25.

5. Bonifaz A, Chang P, Moreno K, et al. Disseminated cutaneous histoplasmosis in acquired immunodeficiency syndrome: report of 23 cases. Clin Exp Dermatol. 2009;34(4):481-6.

6. Saheki MN, Schubach A0, Salgueiro MM, et al. Histoplasmose cutânea primária: relato de caso em paciente imunocompetente e revisão de literatura [Primary cutaneous histoplasmosis: case report on an immunocompetent patient and review of the literature]. Rev Soc Bras Med Trop. 2008;41(6):680-2.

7. Passoni LFC, Ribeiro SR, Sidi LC, et al. Histoplasmose disseminada como primeira manifestação de aids: um diagnóstico tardio demais. Revista Médica. 2003;37(1). Available from: http://www.hse.rj.saude.gov.br/profissional/revista/37/histopla.asp. Accessed in 2010 (May 20).

8. Mehta V, De A, Balachandran C, Monga P. Mucocutaneous histoplasmosis in HIV with an atypical ecthyma like presentation. Dermatol Online J. 2009;15(4):10.

9. Felix F, Gomes GA, Pinto PC, et al. Nasal histoplasmosis in the acquired immunodeficiency syndrome. J Laryngol Otol. 2006;120(1):67-9.

10. Motta AC, Galo R, Lourenço AG, et al. Unusual orofacial manifestations of histoplasmosis in renal transplanted patient. Mycopathologia. 2006;161(3):161-5.

11. Cappell MS, Mandell W, Grimes MM, Neu HC. Gastrointestinal histoplasmosis. Dig Dis Sci. 1988;33(3):353-60.

12. Zighelboim J, Goldfarb RA, Mody D, et al. Prostatic abscess due to Histoplasma capsulatum in a patient with the acquired immunodeficiency syndrome. J Urol. 1992;147(1):166-8.

13. Conces DJ, Stockberger SM, Tarver RD, Wheat U. Disseminated histoplasmosis in AIDS: findings on chest radiographs. AJR Am J Roentgenol. 1993;160(1):15-9.

14. Houston S. Tropical respiratory medicine. 3. Histoplasmosis and pulmonary involvement in the tropics. Thorax. 1994;49(6):598-601.

15. Williams B, Fojtasek M, Connolly-Stringfield P, Wheat J. Diagnosis of histoplasmosis by antigen detection during an outbreak in Indianapolis, Ind. Arch Pathol Lab Med. 1994;118(12):1205-8.

16. Wheat J, Hafner R, Korzun AH, et al. Itraconazole treatment of disseminated histoplasmosis in patients with the acquired immunodeficiency syndrome. AIDS Clinical Trial Group. Am J Med. 1995;98(4):336-42.

17. Raza J, Harris MT, Bauer JJ. Gastrointestinal histoplasmosis in a patient with acquired immune deficiency syndrome. Mt Sinai J Med. 1996;63(2):136-40.

18. Bradsher RW. Histoplasmosis and blastomycosis. Clin Infect Dis. 1996;22 Suppl 2:S10211.

19. Scully C, de Almeida OP, Sposto MR. The deep mycoses in HIV infection. Oral Dis. 1997;3 Suppl 1:S200-7.

20. Knapp S, Turnherr M, Dekan G, et al. A case of HIV-associated cerebral histoplasmosis successfully treated with fluconazole. Eur J Clin Microbiol Infect Dis. 1999;18(9):658-61.

21. Ferreira OG, Cardoso SV, Borges AS, Ferreira MS, Loyola AM. Oral histoplasmosis in Brazil. Oral Surg Oral Med Oral Pathol Oral Radiol Endod. 2002;93(6):654-9.

22. Cantor AG, John J, Brown B. Metrorrhagia in a human immunodeficiency virus positive woman caused by cervical histoplasmosis. Am J Med Sci. 2010;339(3):285-7.

23. Small P, Levitt P. Disseminated histoplasmosis and necrotizing vasculitis. Can Med Assoc J. 1976;114(2):140-1, 145.

Conflict of interest: None

Sources of funding: Fundação de Amparo à Pesquisa do Estado de São Paulo (Fapesp grant number 2006/50084-2) and Conselho Nacional de Desenvolvimento Científico e Tecnológico (CNPq grant number 474531/2008-2) to NM Matsuda.

Date of first submission: June 10, 2009

Last received: June 10, 2010

Accepted: June 11, 2010
Address for correspondence:

Alice Tatsuko Yamada

Instituto do Coração (InCor), Hospital das Clínicas da Faculdade de Medicina da Universidade de São Paulo (HC-FMUSP)

Av. Dr. Enéas de Carvalho Aguiar, 44

São Paulo (SP) - Brasil

CEP 05403-000

Tel. (+55 11) 5512-4566 - Fax. (+55 11) 3082-2354

E-mail: alice.yamada@incor.usp.br 